\title{
Local control of subaerial large igneous provinces on Paleoproterozoic seawater isotopic composition: a Nd perspective.
}

\author{
F. NARDUZZI ${ }^{1,2 *}$, D BosCH $^{2}$, P. PHILIPPOT ${ }^{2,1,3}$
}

${ }^{1}$ IAG, Universidade de São Paulo, Brazil

(*correspondance: france.nardo@iag.usp.br)

${ }^{2}$ Géosciences Montpellier, Université Montpellier, France

${ }^{3}$ Institut de Physique du Globe de Paris, Paris, France

The increase in the proportion of subaerial large igneous provinces (LIPs) and associated emergence of continental surface has been considered as a driven mechanism of the rise of atmospheric $\mathrm{O}_{2}$ during the Archean-Proterozoic transition [Great Oxidation Event (GOE) between 2.45 and $2.2 \mathrm{Ga}$ ]. However, direct geochemical evidence between subaerial LIPs emplacement, oxidative weathering of emerged continental surfaces and the GOE is still lacking. A suitable locality to test this model is the Hamersley basin of Western Australia, where the Turee Creek Group and the underlying Hamersley and Fortescue groups hosting the Wongarra, Weeli Wolli and Fortescue LIPs, form a continuous sedimentary sequence deposited between $\sim 2.8$ and $2.1 \mathrm{Ga}$. Here we report the $\mathrm{Nd}$ isotope composition of the different sedimentary rocks forming the Turee Creek Group (shales, glacial diamictites and carbonates) and underlying Boolgeeda Iron Formation (BIFs and diamictites).

In a mafic-felsic-weathering (MFW) diagram, BIFs, shales, glacial diamictites and carbonates forming the Hamersley and Turee Creek groups overlap the Fortescue LIP. In a $\varepsilon \mathrm{Nd}_{\mathrm{t}}$ vs. ${ }^{147} \mathrm{Sm} /{ }^{144} \mathrm{Nd}$ diagram, these sediments define two trends originating from a similar hydrothermal source but diverging towards two different continental reservoirs; a radiogenic source represented by the Fortescue LIP of the south Hamersley Basin and a crustally-contaminated source represented by the Fortescue LIPs of the north Hamersley Basin. BIFs selected for their seawater-like REY patterns and aluminium $\mathrm{Al}$ contents $<1 \mathrm{wt} . \%$ display $\varepsilon \mathrm{Nd}_{\mathrm{t}}$ overlapping the two LIP reservoirs, which argues for a local control of basinal seawater compositions through time. These results and their implications in terms of alteration of emerged continental surfaces attending the GOE are discussed in light of available trace element and $\mathrm{Nd}$ isotope data from other ArcheanPaleoproterozoic cratons. 